
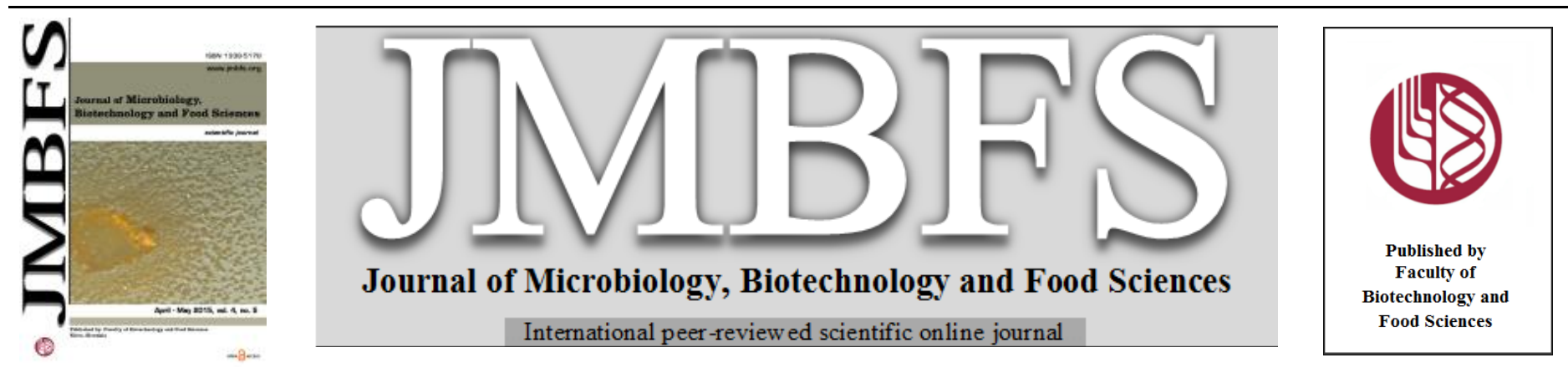

\title{
IMPACT OF BACTERIAL QUORUM SENSING SYSTEM ON CHANGES OF ORGANOLEPTIC MARKERS OF STORAGE CABBAGE
}

\author{
Kamila Myszka ${ }^{*}$, Mariola Olkowicz ${ }^{I}$, Elżbieta Radziejewska-Kubzdela ${ }^{2}$, Agnieszka K. Olejnik-Schmidt ${ }^{1}$, Katarzyna Czaczyk $^{l}$ \\ Address(es): Dr. Kamila Myszka, \\ ${ }^{1}$ Poznan University of Life Sciences, Department of Biotechnology and Food Microbiology, Wojska Polskiego 48, 60-627 Poznan, Poland. \\ ${ }^{2}$ Poznan University of Life Sciences, Institute of Food Technology, Wojska Polskiego 31, 60-624 Poznan, Poland.
}

*Corresponding author: kmyszka@up.poznan.pl

doi: 10.15414/jmbfs.2015.4.5.407-411

\section{ARTICLE INFO}

Received 2. 10. 2013

Revised 26. 1. 2015

Accepted 16. 2. 2015

Published 1. 4. 2015

Regular article

OPEN $\partial_{\text {ACCESS }}$

\section{ABSTRACT}

The regulation of phenotypes of vegetable-associated bacteria can be mediated through the production of acylated homoserine lactones (AHLs). This knowledge is essential for successful control of bacterial diseases of vegetable. The purpose of these investigations was to define the AHL patterns of gram-negative bacteria presented in storage cabbage by LC/MS technique. The phenomenon of regulating the pectinolytic activity and the exopolysaccharide (EPS) production by AHLs that are associated with microbial spoilage of cabbage was also examined. Among 100 strains isolated from storage cabbage, 47 isolates produced AHLs. The results of the 16S rDNA sequence analysis indicated that selected microflora was highly closely related to Pantoea agglomerans, Rahnella aquatilis, Pseudomonas fluorescens, Pseudomonas syringae, and Pseudomonas cedrina (approximately 98\%-99\% confidence). The chemical nature of AHLs produced by selected microflora differ from species to species. The pattern of AHLs of Ps. cedrina consisting of $\mathrm{C}_{8-}$ HSL, 3-oxo- $\mathrm{C}_{10}-\mathrm{HSL}$, and 3-hydroxy- $\mathrm{C}_{14}-\mathrm{HSL}$, has not been previously reported. The present study demonstrates that bacterial spoilage of storage cabbage is influenced by quorum sensing. Application of furanone C-30 that acts as quorum sensing inhibitor, caused the significant reduction in the production of EPS and pectinolytic enzymes by examined bacteria.

Keywords: Enterobacteriaceae, quorum sensing, acylated homoserine lactones, storage cabbage, microbiological spoilage

\section{INTRODUCTION}

Microbial spoilage of vegetables during storage is an area of global concern Despite modern storage facilities, approximate $25-30 \%$ of all vegetables are lost due to microbial activity (Ragaert et al., 2007). An improved science-based understanding of the activity of microorganisms present in storage vegetables is crucial for the increase reduction of the rate of microbial degradation of foods and development of novel prevention techniques.

The studies of Rasch et al. (2005) and Medina-Martinez et al. (2006) have demonstrated that metabolism of plant-associated bacteria is quorum sensingregulated. In gram-negative bacteria this regulation is typically mediated by chemical signals such as $N$-acyl-L-homoserine lactones (AHLs). AHLs have a conserved homoserine lactone (HSL) ring which is acylated with a fatty acyl group at the $\alpha$-position. AHLs may contain C4 to $\mathrm{C} 18$ acyl side chains and, at the third carbon, either an oxo, or a hydroxyl, or no substitution (Whitehead et al. 2001 and Myszka and Czaczyk, 2012). The key regulatory components of the quorum sensing mechanism are LuxI-type proteins acting as AHL synthases, serving as AHL molecules receptors, and AHL-dependent transcription factors (Whitehead et al., 2001). The studies of phytopathogens have revealed that degradative enzymes production can be AHL-regulated and such activities may play a role in food spoilage (Burger et al., 2000). In addition, a variety of phytopathogens can produce the same AHLs, but whether these molecules are involved in the regulation of different phenotypes in each strain, or not, needs further investigations (Whitehead et al., 2001).

As foods spoilage is the result of not only bacterial activity, but also chemica changes, the discovery of AHL-positive strains in products by Rasch $\boldsymbol{e t}$ al (2005) and Medina-Martinez et al. (2006) inspired us to investigate if and how quorum sensing influences on the metabolism of bacteria colonizing the vegetables during postharvest storage. Our interest was focused on chopping cabbage. Increasing the consumers' health awareness, together with their demand for convenience foods, have accelerated the global sale of the cabbage. Cabbage contains sulforaphane, which has anticancer properties. Consumption of salads composed of raw chopping cabbage has been shown to reduce the risk of various cancers in human studies (Verkerk et al., 2009). Our preliminary study of microbiological quality of cruciferous vegetables cultivating in Wielkopolska
District revealed the domination of psychrotrophic gram-negative bacteria belonging the genera Pseudomonas. In all examined samples the amount of lactic acid bacteria, Clostridium spp., molds and yeasts did not exceed the value of $10^{1} \mathrm{CFU} / \mathrm{g}$ (unpublished data).

The aim of this study was to define the AHL patterns of gram-negative bacteria presented in chopping cabbage. The phenomena of regulating the phenotypes by quorum sensing that are associated with microbial food spoilage were also examined.

\section{MATERIALS AND METHODS}

\section{Plant material and preparation}

White cabbage (Brassica oleracea L. spp. Olearacea convar capitata) came from a farm in western Poland. The cabbage was grown in the open air on loam soil. After harvesting vegetables were storied at $4^{\circ} \mathrm{C}$ until further experiments. Samples were washed upon running water. The outer leaves of the cabbage were removed and dried on blotting paper. After drying, the samples of cabbage were mechanically comminuted with a Nagema HU-1 cabbage slicer (Dresden, Germany). Comminuted product was weighed in the amount of $200 \mathrm{~g}$ to polypropylene trays of $205 \times 160 \times 60 \mathrm{~mm}$, with oxygen permeability of 7-8 $\mathrm{cm}^{3} / \mathrm{m}^{2} / 24 \mathrm{~h}$. Tested vegetable product was packaged in air atmosphere and storied at $4^{\circ} \mathrm{C}$ for 12 days.

\section{Enumeration and isolation of psychrotrophic gram-negative bacteria}

The samples of cabbage were diluted $1: 9$ with physiological saline $(0.9 \% \mathrm{NaCl})$ homogenized in a stomacher for $2 \mathrm{~min}$, and serially 10-fold diluted. Aerobic counts of bacteria of the family Enterobacteriaceae were made on MacConkey agar (Oxoid, UK) incubated at $15^{\circ} \mathrm{C}$ for 3 days. After incubation period, colonies from MacConkey agar were isolated and inoculated in LB according to Bertan (1951) ( $1 \%$ peptone, $0.5 \%$ yeast extract, $0.5 \% \mathrm{NaCl})$. Then cultures were incubated at $15^{\circ} \mathrm{C}$ for 3 days. 
Screening for AHL-producing of gram-negative bacteria by replica planting

The screening of obtained isolates for AHL-production was performed according to the methods of Ravn et al. (2001). According to the method Agrobacterium tumefaciens ATCC 51350 and Chromobacterium violaceum ATCC 31532 were used as AHL monitor strains to screen for AHL-producing microflora. The tested strains were streaked in parallel to the monitor strains on LB agar plates. $A$ tumefaciens carries a lac Z fusion to a traI and produces a blue color in a presence of 5-bromo-4-chloro-3-indolyl- $\beta$-D-galactopyranoside $(\mathrm{X}-\mathrm{Gal})$ in response to AHL (Ravn et al., 2001). A. tumefaciens have a high affinity for long chained AHL ( $\geq \mathrm{C} 8$ ). The CviR of $C$. violaceum regulates the production of a purple pigment when induced by AHL. C. violaceum is induced by $\mathrm{C} 4-\mathrm{C} 8$ unsubstituted AHL (McClean et al., 1997). All plates were incubated for 3 days at $15^{\circ} \mathrm{C}$.

\section{Sequencing and phylogenetic analysis}

After initial bacterial biomass incubation in $10 \mathrm{mM}$ Tris- $\mathrm{Cl} \mathrm{pH} 7.5$ with 50 $\mathrm{mg} / \mathrm{mL}$ lysozyme (Sigma, USA) for $0.5 \mathrm{~h}$ at $37^{\circ} \mathrm{C}$, total DNA from cells was extracted using Genomie Mini AX Bacteria Kit (A\&A Biotechnology, Gdańsk, Poland). Sequences encoding small subunit of rRNA were amplified in PCR reaction using primers SDBact0008aS20 and SUniv1492bA21 (Suau et al., 1999). PCR was performed in total volume of $50 \mathrm{uL}$ containing $1 \times P C R$ buffer (20mM Tris- $\mathrm{HCl}, \mathrm{pH} 8.8,2.0 \mathrm{mM} \mathrm{MgSO}_{4}, 10 \mathrm{mMKCl}$ and $0.1 \%$ Triton $\mathrm{X}-100$ ) additional $\mathrm{MgCl}_{2}$ to concentration of $2.5 \mathrm{mM} \mathrm{MgCl}_{2}, 100 \mathrm{ng}$ DNA template, 0.44 $\mathrm{mM}$ concentration of each primer, 200uM dNTP, 1.25 U RUN DNA polymerase (A\&A Biotechnology, Poland). PCR was carried out in Biometra T Gradient thermocycler (Biometra, Germany). The amplification of 16S rDNA consisted 30 cycles of $1 \mathrm{~min}$ denaturation step at $94^{\circ} \mathrm{C}, 1 \mathrm{~min}$ annealing step at $48^{\circ} \mathrm{C}$, and 1.5 min extension at $72^{\circ} \mathrm{C}$. Negative controls containing no DNA template were included in parallel. Four microliter samples of PCR product were analyzed by electrophoresis in $1.0 \%(\mathrm{w} / \mathrm{v})$ agarose in $1 \mathrm{x}$ TBE buffer $(89 \mathrm{mM}$ Tris-borate, $2 \mathrm{mM}$ EDTA $\mathrm{pH} 8.3$ ) and then they were subsequently visualized by illumination after ethidium bromide staining. PCR products were purified using Clean-up Kit according to user manual (A\&A Biotechnology, Gdańsk, Poland) and sequenced at Genomed (Warszawa, Poland) with primers used for PCR and additionally for inner sequence with GTGCCAGCMGCCGCCCTAA primer. Obtained sequences were arranged into contigs and identified in BLAST service of the GenBank database (Altschul et al., 1990).

\section{LC-MS analysis}

Extracts for LC-MS analysis were prepared from $100 \mathrm{ml}$ cultures after growth in $\mathrm{LB}$ medium for 3 days at $15^{\circ} \mathrm{C}$. Bacteria were removed by centrifugation; the supernatants were extracted twice with equal volumes of ethyl acetate acidified with $0.5 \%$ of formic acid. Extracts were evaporated to dryness, redissolved in methanol (gradient grade), and analyzed on an Agilent 1200 series liquid chromatograph equipped with a DAD detector coupled to a high resolution, timeof-flight (TOF) mass spectrometer (Agilent 6224) with a ESI source. Extracts at volume of $20 \mu \mathrm{l}$ were injected on the Nucleosil $\mathrm{C}_{18}$ column (particle size $5 \mu \mathrm{m}$, $125 \times 4 \mathrm{~mm})$. The analyzes were done at a flow rate of $1 \mathrm{ml} / \mathrm{min}$ with a wateracetonitrile gradient, starting at acetonitrile-water (5:95), going to $100 \%$ acetonitrile in $30 \mathrm{~min}$, and maintaining $100 \%$ acetonitrile for $5 \mathrm{~min}$, before returning to the start conditions in $15 \mathrm{~min}$, and equilibrating for $10 \mathrm{~min}$. The UV spectra were collected by DAD at $195 \mathrm{~nm}$. MS spectra were obtained in positive ion electrospray mode. The mass spectrometer parameters were as follows: capillary voltage $-3500 \mathrm{~V}$, scan acquisition - from 100 to $500 \mathrm{~m} / \mathrm{z}$, desolvation gas flow and temperature: $11 \mathrm{~L} / \mathrm{min}$ and $325^{\circ} \mathrm{C}$ respectively, nebulizer gas -20 psi, fragmentor voltage $-150 \mathrm{~V}$.

\section{Investigation of AHL-regulated phenotypes}

An involvement of AHL in regulation of EPS production and pectinolytic activity of bacterial isolates was examined by adding $0.9 \mu \mathrm{g} / \mathrm{ml}$ of furanone C-30 (Sigma USA) to freshly inoculated cultures in LB medium (Wu et al., 2004). Furanone C-30 acts as bacterial quorum sensing inhibitor. The cultures that grew on LB medium without furanone $\mathrm{C}-30$ component were used as reference. The incubation was conducted at $15^{\circ} \mathrm{C}$ for 3 days. The amount of viable cells in the samples was examined by pour plate method.

The presence of pectinolytic activity was evaluated by spotting $10 \mu \mathrm{l}$ of examined cultures on agar plates containing $1 \%(\mathrm{w} / \mathrm{v})$ of polygalacturonic acid (Sigma, USA). The plates were incubated for 3 days at $15^{\circ} \mathrm{C}$. After the colonies reached around $3 \mathrm{~mm}$, iodine-potassium iodide solution $(1.0 \mathrm{~g}$ iodine, $5.0 \mathrm{~g}$ potassium iodide and $330 \mathrm{ml} \mathrm{H}_{2} \mathrm{O}$ ) was added to detect clearance zones (Bowen and Kominos, 1979).

The ability to synthesize EPS was determined using the procedure employed by Forde and Fitzgerald (1999). The bacteria were harvested by centrifugation at $3000 \mathrm{~g}$ for $20 \mathrm{~min}$ at the room temperature. The cells were resuspended in $1.5 \mathrm{ml}$ of $30 \%(\mathrm{w} / \mathrm{v}) \mathrm{NaOH}$. Samples were boiled for $15 \mathrm{~min}$, centrifuged at $15000 \mathrm{~g}$ for $15 \mathrm{~min}$, and the supernatant fluids were added dropwise to $60 \%(\mathrm{v} / \mathrm{v})$ ethanol The total EPS (expressed as $\mu \mathrm{g} / \mathrm{CFU}$ ) was determined using the acid hydrolysis method of Parkar et al. (2001). The precipitated EPS was collected by centrifugation $(15000 \mathrm{~g}, 20 \mathrm{~min})$, and was resuspended in $1 \mathrm{ml}$ of sterile water. The samples were mixed with $7 \mathrm{ml}$ of $77 \%(\mathrm{v} / \mathrm{v}) \mathrm{H}_{2} \mathrm{SO}_{4}$ and cooled for $10 \mathrm{~min}$ in an ice-bath. $1 \mathrm{ml}$ of $1 \%(\mathrm{w} / \mathrm{v})$ of cold tryptophan was added and the samples were heated in a boiling bath for $20 \mathrm{~min}$ to affect hydrolysis. The acid hydrolysis of EPS produced a furan which condenses with the tryptophan and forms a colored product. The calibration curves were prepared against standard dextran (Mp. 40000) solutions (Sigma, USA).

\section{RESULTS AND DISCUSSION}

\section{Isolation and identification of AHL-producing psychrotrophic strains}

Psychrotrophic strains of the family Enterobacteriaceae are frequent members of the spoilage microflora of storage vegetables (Ragaert et al., 2007). The total counts of gram-negative rods in refrigerated cabbage can range from $10^{3}$ to $10^{5}$ CFU/g (Ragaert et al., 2007). In this work the initial population of psychrotrophic members of Enterobacteriaceae in storage cabbage reached the average level of $5.0 \times 10^{2} \mathrm{CFU} / \mathrm{g}$ (Tab 1). The population increased to $2.0 \times 10^{4}$ $\mathrm{CFU} / \mathrm{g}$ after 6 days and then gradually reached the value of $3.5 \times 10^{7} \mathrm{CFU} / \mathrm{g}$ during the remainder 6-days period of storage (Tab 1).

In this study for further investigations one hundred randomly picked colonies were isolated from MacConkey agar plates. All isolates produced pink to red mucoid colonies with a reddish bile precipitate surrounding. The ability of selected bacteria to synthesize AHL molecules was evaluated using $A$ tumefaciens and $C$. violaceum as AHL-monitoring strains. Of 100 strains isolated from storage cabbage, 47 elicited a response A. tumefaciens, which detects mainly 3-oxo-AHLs with acyl chain lengths from 6 to $14 \mathrm{C}$ atoms. In the work, 45 isolates were positive in the $C$. violaceum assay, which detects nonsubstitued AHL molecules.

The results of the $16 \mathrm{~S}$ rDNA sequence analysis indicated that AHL-positive isolates were closely related to Pseudomonas spp. and Pantoea spp. and Rahnella spp. (approximately 98\%-99\% confidence). Pantoea agglomerans, Pseudomonas fluorescens, and Pseudomonas orientalis were the dominant AHL-positive microflora in examined samples, except for an occasional isolation of Rahnella aquatilis and Pseudomonas cedrina (Tab 1). These observations were similar to the findings of Simon-Sarkadi et al. (1993) who reported that Enterobacteriaceae population represents up to $90 \%$ of the total microbial number of cut cabbage Brassica pekinensis Rupr. stored at $5^{\circ} \mathrm{C}$. Microbiological populations were mostly situated on cut surface of the cabbage (Simon-Sarkadi et al., 1993).

Table 1 Detection and identification of AHL-synthesizing bacteria in chopped cabbage

\begin{tabular}{|c|c|c|c|c|c|c|c|c|c|}
\hline \multirow{2}{*}{$\begin{array}{l}\text { Number of } \\
\text { sample }\end{array}$} & \multirow{2}{*}{$\begin{array}{c}\text { Storage } \\
\text { time } \\
\text { (days) }\end{array}$} & \multirow{2}{*}{$\begin{array}{c}\text { Total number of } \\
\text { psychrotrophic } \\
\text { Enterobacteriaceae }[\mathrm{CFU} / \mathrm{g}]\end{array}$} & \multirow{2}{*}{$\begin{array}{c}\text { number of } \\
\text { isolates }\end{array}$} & \multirow{2}{*}{$\begin{array}{c}\text { Number of } \\
\text { AHL-positive } \\
\text { isolates }\end{array}$} & \multicolumn{5}{|c|}{ Identification of AHL-positive isolates } \\
\hline & & & & & $\begin{array}{c}P . \\
\text { agglomerans } \\
\end{array}$ & $\begin{array}{c}R . \\
\text { aquatilis } \\
\end{array}$ & $\begin{array}{c}\text { Ps. } \\
\text { fluorescnes } \\
\end{array}$ & $\begin{array}{c}\text { Ps. } \\
\text { orientalis } \\
\end{array}$ & $\begin{array}{c}\text { Ps. } \\
\text { cedrina } \\
\end{array}$ \\
\hline \multirow{3}{*}{1} & 0 & $9.0 \times 10^{2}$ & 6 & 2 & 1 & & & 1 & \\
\hline & 6 & $2.1 \times 10^{4}$ & 12 & 5 & 4 & & & 1 & \\
\hline & 12 & $3.6 \times 10^{7}$ & 15 & 8 & 5 & 1 & & 2 & \\
\hline \multirow{3}{*}{2} & 0 & $3.0 \times 10^{2}$ & 3 & 1 & & & 1 & & \\
\hline & 6 & $1.9 \times 10^{4}$ & 14 & 6 & 3 & & 3 & & \\
\hline & 12 & $3.3 \times 10^{7}$ & 28 & 10 & 5 & & 3 & & 2 \\
\hline \multirow{3}{*}{3} & 0 & $5.0 \times 10^{2}$ & 2 & 1 & & & 1 & & \\
\hline & 6 & $1.9 \times 10^{4}$ & 8 & 4 & & & 3 & 1 & \\
\hline & 12 & $3.5 \times 10^{7}$ & 12 & 10 & 5 & & 2 & 3 & \\
\hline
\end{tabular}




\section{Profiles of AHL molecules of selected bacteria}

In the work, for screening the capability of isolated microflora for the production of AHLs, the liquid chromatography (LC) coupled to MS was applied. The attribution of chromatographic peaks to AHLs was confirmed by the MS at the range of $\mathrm{m} / \mathrm{z}, 100$ to 500. Selected results of LC-MS analyses for cell-free supernatant of Ps. fluorescens PF7 are shown in Figure 1, 2 and 3.

The examples of AHL profiles of isolates obtained in this work were presented in $\mathrm{Tab} 2$. In the study, in extracts of cell-free supernatants of gram-negative isolates, several AHLs were identified. Interestingly, all examined samples showed the presence of $\mathrm{C}_{8}$-HSL. Significant differences between the AHLs profiles of tested microflora were noted at the level of late-eluting signal molecules (AHLs with C9 and C14 acyl chains) (Tab 2). Results obtained in this work also indicate that the chemical nature of quorum sensing signal molecules differs from species to species. All of isolates of the genus of Pseudomonas produced different AHLs, which vary in the length and substitution of the acyl chain. The pattern of AHLs of Ps. cedrina consisting of $\mathrm{C}_{8}$-HSL, 3-oxo- $\mathrm{C}_{10}$ - HSL, and 3-hydroxy- $\mathrm{C}_{14}-\mathrm{HSL}$, has not been previously reported.

Our results show essential differences in the spectra of AHLs in comparison to the published data for the same bacterial cultures. According to Whitehead et al. (2001) the production of AHLs by gram-negative bacteria is dominated by synergistic effect of the surrounding environment. Through signaling mechanisms bacteria also respond to metabolic activity of other species colonizing the same niche (Whitehead et al., 2001). Bacterial cultures isolated from: potato ( $P$. agglomerans), drinking water ( $R$. aquatilis), and root hairs of a sugar beet plants ( $P$ s. fluorescens) were capable to synthesize mostly the shortchained signal molecules (Lane et al., 2000; Dong et al., 2001; Steidle et al., 2001; Liu and Griffiths, 2003). In our study LC-MS analysis of the AHLs produced by $P$. agglomerans, $R$. aquatilis, Ps. fluorescens, and Ps. syringae revealed the long-chained signal molecules (AHLs with C8 and C14 acyl chains) (Tab 2)

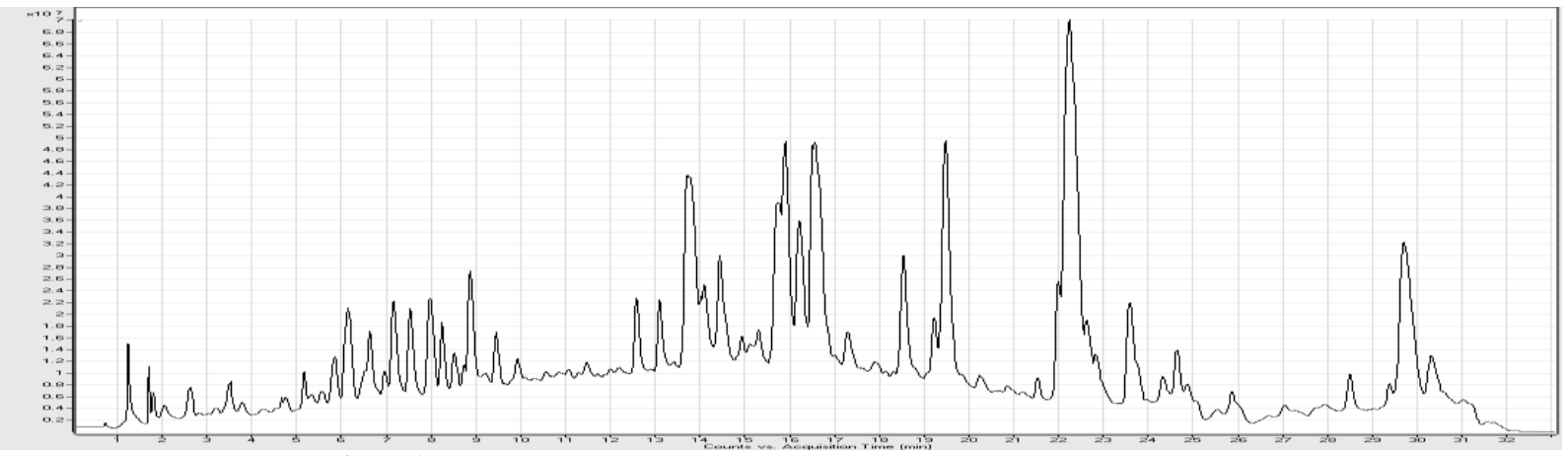

Figure 1 HPLC chromatogram of extracted AHL from Ps. fluorescens PF7 culture

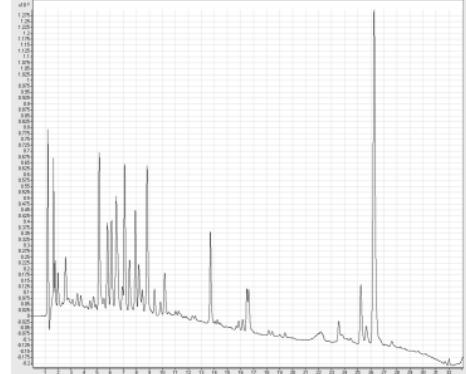

a)

b)
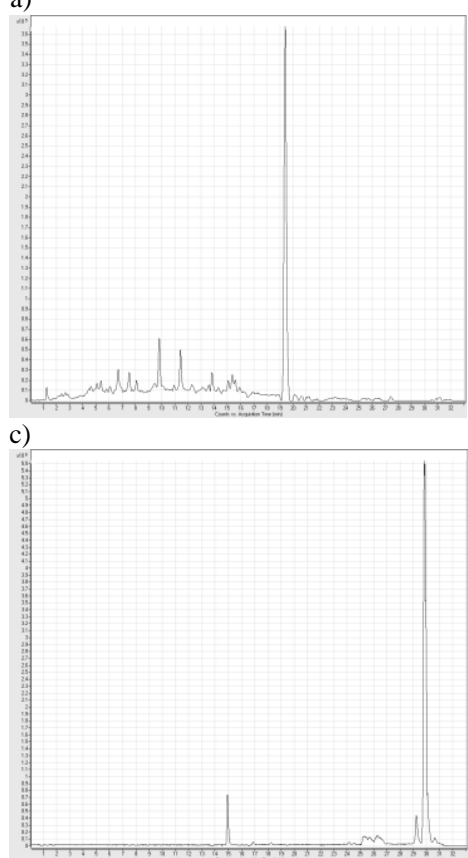

e)

Figure 2 Positive electrospray ionization MS chromatograms ( $a-f$ ), showin appropriately: the total ion current (TIC) $(a)$ and extracted ions for $\left[\mathrm{M}+\mathrm{H}^{+}\right.$ adducts of five detected homoserine lactones: N-3-oxo- $\mathrm{C}_{10}-\mathrm{HSL}(b), \mathrm{N}-\mathrm{C}_{6}-\mathrm{HSL}$ $(c), \mathrm{N}-3$-oxo- $\mathrm{C}_{14}$-HSL $(d), \mathrm{N}^{-} \mathrm{C}_{8}$-HSL $(e), \mathrm{N}-\mathrm{C}_{10}$-HSL $(f)$

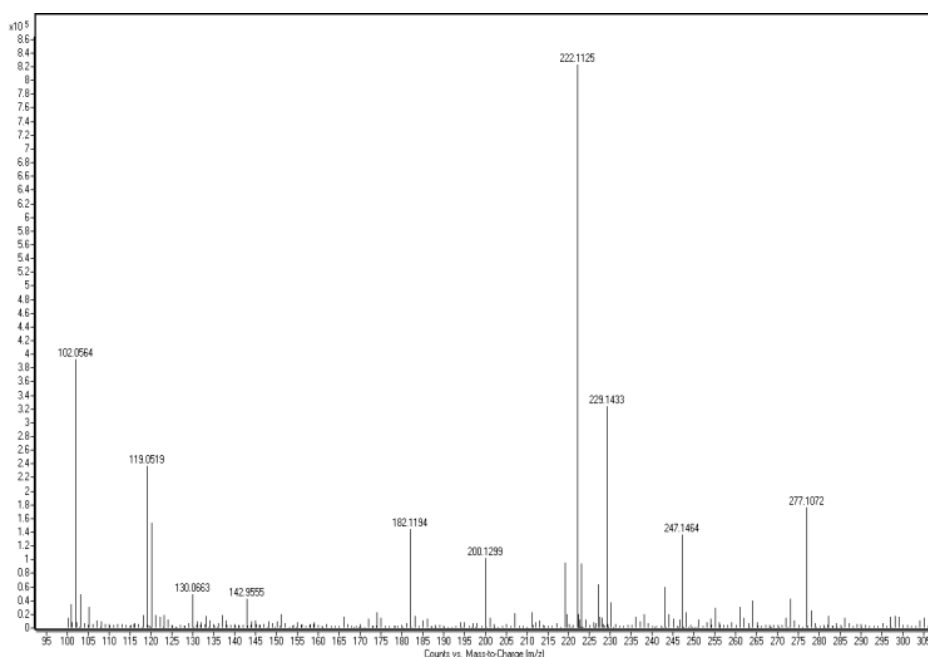

Figure 3 The mass spectrum for selected homoserine lactone (identified above) $-\mathrm{N}-\mathrm{C}_{6}$-HSL with the proper values of adducts:

1) $\mathrm{m} / \mathrm{z}=200.1299-\left[\mathrm{M}+\mathrm{H}^{+}\right]$,

2) $\quad \mathrm{m} / \mathrm{z}=222.1125-\left[\mathrm{M}+\mathrm{Na}^{+}\right]$

3) $\mathrm{m} / \mathrm{z}=182.1194-\left[\mathrm{M}-\mathrm{H}_{2} \mathrm{O}+\mathrm{H}^{+}\right]$ 
Table 2 Comparison of the profiles of AHLs of obtained isolates with literature data

\begin{tabular}{|c|c|c|c|}
\hline Bacteria & $\begin{array}{c}\text { AHLs identified by LC-MS in this } \\
\text { work }\end{array}$ & literature data & Reference \\
\hline P. agglomerans $P A 4$ & $\begin{array}{c}\mathrm{C}_{8} \text {-HSL; 3-oxo-C }{ }_{10} \text {-HSL; } \\
\text { 3-oxo- } \mathrm{C}_{11} \text {-HSL } \\
\end{array}$ & 3-oxo- $\mathrm{C}_{6}$-HSL & Dong et al. 2001 \\
\hline R. aqatilis $R A$ & $\begin{array}{l}\mathrm{C}_{8}-\mathrm{HSL} ; \mathrm{C}_{10}-\mathrm{HSL} \\
\text { 3-oxo- } \mathrm{C}_{14}-\mathrm{HSL} \\
\end{array}$ & 3-oxo- $\mathrm{C}_{6}$-HSL; 3-oxo- $\mathrm{C}_{8}$-HSL & Steidle et a., 2001 \\
\hline Ps. fluorescens PF 7 & $\begin{array}{c}\mathrm{C}_{6}-\mathrm{HSL} ; \mathrm{C}_{8}-\mathrm{HSL} ; \mathrm{C}_{10}-\mathrm{HSL} \\
\text { 3-oxo-C } \\
\text { - }{ }_{10} \text {-HSL; 3-oxo-C } \\
14-\mathrm{HSL}\end{array}$ & $\begin{array}{c}\mathrm{C}_{4}-\mathrm{HSL} ; \mathrm{C}_{6}-\mathrm{HSL} ; \\
\text { C3-oxo-C }_{6}-\mathrm{HSL} ; \mathrm{C}_{14}-\mathrm{HSL}\end{array}$ & $\begin{array}{c}\text { Lane et al., 2000; } \\
\text { Liu and Griffiths, } 2003\end{array}$ \\
\hline Ps. syringae PS 2 & $\mathrm{C}_{8}$-HSL; 3-oxo-C ${ }_{8}-\mathrm{HSL} ; \mathrm{C}_{9}$-HSL, & 3-oxo- $\mathrm{C}_{6}$-HSL & Cha et al., 1998 \\
\hline Ps. cedrina PC 2 & $\begin{array}{l}\mathrm{C}_{8}-\mathrm{HSL} ; 3 \text {-oxo-C } \mathrm{C}_{10}-\mathrm{HSL} \\
\text { 3-hydroxy-C } \\
\text {-hySL }\end{array}$ & no data & no data \\
\hline
\end{tabular}

\section{Characterization of bacterial AHL-regulated phenotypes}

Gram et al. (2002) demonstrated that nutrients composition of chill-stored vegetables allows the gram-negative bacteria to grow, but only the fraction of these microorganisms present in storage products (typically Pseudomonas spp and Pantoea spp.) cause the spoilage characteristics. The metabolism of phytopathogenic bacteria can be oriented to secretion of pectinolytic enzymes and production of EPS (Denny, 1995; Jayani et al., 2005). Pectinolytic enzymes cause the maceration of plant tissues (Jayani et al., 2005). Bacterial EPS, due to their normally high viscosity, cause vascular plugging of plants leading to wilting. According to Denny (1995), the production of EPS favors disease development by masking bacterial cell wall, thus protecting the cells from preformed antimicrobial compounds.

In the work we examined whether quorum sensing inhibition had any effect on pectinolytic activity and exopolysaccharides production by microflora of storage cabbage. The influence of the supplementation of the culture medium with furanone C-30 on tested bacterial growth is presented in Tab 3. The differences in metabolic activity of AHL-positives isolates and isolates with interrupting quorum sensing by furanone C-30, are shown in Tab4.

Table 3 The influence of the supplementation of the culture medium with furanone $\mathrm{C}-30$ on tested bacterial growth

\begin{tabular}{|c|c|c|}
\hline \multirow{2}{*}{ Isolate } & \multicolumn{2}{|c|}{$\begin{array}{l}\text { Cell number in the medium } \\
(\mathrm{CFU} / \mathrm{ml})\end{array}$} \\
\hline & $\begin{array}{c}\text { medium without } \\
\text { furanone C-30 }\end{array}$ & medium with furanone $\mathrm{C}-30$ \\
\hline $\begin{array}{l}P . \\
\text { agglomerans } \\
\text { PA4 }\end{array}$ & $3.0 \times 10^{6}$ & $1.5 \times 10^{2}$ \\
\hline $\begin{array}{l}\text { R. aqatilis } \\
\text { RA1 }\end{array}$ & $6.7 \times 10^{6}$ & $5.5 \times 10^{2}$ \\
\hline $\begin{array}{l}\text { Ps.fluorescens } \\
\text { PF7 }\end{array}$ & $5.5 \times 10^{5}$ & $6.8 \times 10^{3}$ \\
\hline $\begin{array}{l}\text { Ps. syringae } \\
\text { PS2 }\end{array}$ & $1.5 \times 10^{6}$ & $3.8 \times 10^{3}$ \\
\hline $\begin{array}{l}\text { Ps. cedrina } \\
\text { PC2 }\end{array}$ & $3.5 \times 10^{5}$ & $2.8 \times 10^{2}$ \\
\hline
\end{tabular}

In our study, furanone C-30 caused significant reduction of tested bacterial growth (Tab 3). In addition, in all of obtained isolates synthesis of EPS and pectinolytic enzymes were quorum sensing-regulated phenotypes (Tab 4). The EPS production capacity of examined bacteria varied between 4.80 to 6.69 [mgEPS $\left./ 10^{7} \mathrm{CFU}\right]$. In this work, the supplementation of the culture medium with furanone C-30 caused significant reduction of EPS biosynthesis. Similarly, the production and secretion of pectinolytic enzymes by tested isolates was under the control of AHLs. Only in Ps. cedrina isolates we did not identify the ability to synthesize pectinolytic enzymes (Tab 4).

Our observations are consistent with the results obtained by Rasch et al. (2005) The authors also noticed that food-associated Enterobacteriaceae were capable to synthesize AHLs. This ability allows bacteria, present at an average concentration of $10^{6} \mathrm{cfu} / \mathrm{g}$, locally to induce expression of phenotypes that would otherwise require an average value of $10^{8} \mathrm{cfu} / \mathrm{g}$ (Bruhn et al., 2004). Bruhn et al (2004) also demonstrated the universal character of AHLs that facilitate interspecies communication between gram-negative strains. According to Bruhn et al. (2004) the ability of Hafnia alvei to produce AHLs facilitated the expression of quorum sensing system in other microorganisms present in stored meat products. If AHLs directly control of bacterial metabolism, such management could be the major mechanism determining the rate of microbiological spoilage of storage foods (Hentzer et al., 2003). The application of quorum sensing inhibitors, which specifically block the AHL production, may enhance the shelf life of most fresh and lightly preserved foods (Hentzer $\boldsymbol{e t}$ al., 2003).

Table 4 Comparison of pectinolytic activity and synthesis of exopolysaccharides by AHL-positive isolates and isolates with inhibited production of AHLs by furanone C-30

\begin{tabular}{|c|c|c|c|c|}
\hline \multirow[b]{2}{*}{ Isolate } & \multicolumn{2}{|c|}{$\begin{array}{c}\text { Production of } \\
\text { exopolysaccharides } \\
{\left[\mathrm{mgEPS} / \mathbf{1 0}^{7} \mathrm{CFU}\right]}\end{array}$} & \multicolumn{2}{|c|}{ Pectinolytic activity $^{\text {a }}$} \\
\hline & $\begin{array}{c}\text { medium } \\
\text { without } \\
\text { furanone C- } \\
30\end{array}$ & $\begin{array}{l}\text { medium with } \\
\text { furanone C- } \\
30\end{array}$ & $\begin{array}{c}\text { medium } \\
\text { without } \\
\text { furanone C- } \\
30\end{array}$ & $\begin{array}{l}\text { medium } \\
\text { with } \\
\text { furanone C- } \\
30\end{array}$ \\
\hline $\begin{array}{l}\text { P.agglomerans } \\
\text { PA4 }\end{array}$ & $\begin{array}{c}6.14 \\
( \pm 0.003)\end{array}$ & $\begin{array}{c}0.1 \\
( \pm 0.001)\end{array}$ & + & - \\
\hline R. aqatilis RA1 & $\begin{array}{c}4.80 \\
( \pm 0.1) \\
\end{array}$ & $\begin{array}{c}0.01 \\
( \pm 0.001) \\
\end{array}$ & + & - \\
\hline $\begin{array}{l}\text { Ps.fluorescens } \\
\text { PF7 }\end{array}$ & $\begin{array}{c}5.13 \\
( \pm 0.5)\end{array}$ & - & + & - \\
\hline $\begin{array}{l}\text { Ps. syringae } \\
\text { PS2 }\end{array}$ & $\begin{array}{c}6.23 \\
( \pm 0.1)\end{array}$ & - & + & - \\
\hline $\begin{array}{l}\text { Ps. cedrina } \\
\text { PC2 }\end{array}$ & $\begin{array}{c}6.69 \\
( \pm 0.2)\end{array}$ & $\begin{array}{c}0.01 \\
( \pm 0.001)\end{array}$ & - & - \\
\hline
\end{tabular}

\section{CONCLUSION}

Our work supports the notion that AHL-based quorum sensing is the common feature of gram-negative bacteria contaminated chill-stored products of vegetable origin. Despite the fact that chemical nature of AHLs differ from species to species, these molecules modulate the same metabolic activity of cells Application of furanone C-30 that acts as quorum sensing inhibitor, caused the significant reduction in the production of EPS and pectinolytic enzymes by examined bacteria. Further studies on the impact of AHL regulation of spoilage of storage vegetables are currently in progress in our laboratory. Analyses of possible importance of AHL-based quorum sensing in spoilage reactions is essential for design novel preservation techniques eliminating the risk of resistance development of bacteria. This knowledge will permit for a more efficient food quality management.

\section{REFERENCES}

ALTSCHUL, S.F., GISH, W., MILLER, W., MYERS, E.W., LIPMAN, D.J. 1990. Basic local alignment search tool. Journal of Molecular Biology, 215, 403 410.

http://dx.doi.org/10.1002/047145916x.ch4

BERTANI, G. 1951. Studies on lysogenesis. 1. The mode of phage liberation by lysogenic Escherichia coli. Journal of Bacteriology, 62, 293-300

BOWEN, J.H., KOMINOS, S.D. 1979. Evaluation of a pectin agar medium for isolation of Yersinia enterocolitica within 48 hours. American Journal of Clinical Pathology, 72, 586-590.

BRUHN, J.B., CHRISTENSEN, A.B., FLODGAARD, L.R., NIELSEN, K.F., LARSEN, K.F., GIVSKOV, M., GRAM, L. 2004. Presence of acylated homoserine lactones (AHLs) and AHL-producing bacteria in meat and potential role of AHL in spoilage of meat. Applied and Environmental Microbiology, 70, 3149-3155. 
http://dx.doi.org/10.1128/aem.70.7.4293-4302.2004

BURGER, M., WOODS, R.G., MCCARTHY, C., BEACHAM., I.R. 2000 Temperature regulation of protease in Pseudomonas fluorescens LS107d2 by an ECF sigma factor and a transmembrane activator. Microbiology, 146, 3149-3155. DENNY, T.P. 1995. Involvement of bacterial polysaccharides in plant pathogens. Annual Review of Phytopathology, 33, 173-197.

http://dx.doi.org/10.1146/annurev.phyto.33.1.173

DONG, Y.H., WANG, L.H., XU, J.L., ZHANG, H.B., ZHANG, X.F., ZHANG, L.H. 2001. Quenching quorum-sensing-dependent bacterial infection by $\mathrm{N}$ acylhomoserine lactone. Nature, 411, 813-817.

FORDE, A., FITZGERALD, G.F. 1999. Analysis of exopolysaccharide (EPS) production mediated by the bacteriphage adsorption blocking plasmid, pCI658, isolated from Lactococcus lactis ssp. cremoris HO2. International Dairy Journal, 9, 465-472.

http://dx.doi.org/10.1016/s0958-6946(99)00115-6

GRAM, L., RAVN, L., RASCH, M., BRUHM, J.B., CHRISTENSEN, A.B., GIVSKOV, M. 2002. Food spoilage-interactions between food spoilage bacteria International Journal of Food Microbiology, 78, 79-97.

http://dx.doi.org/10.1016/s0168-1605(02)00233-7

HENTZER, M., WU, H., ANDERSEN, J.B., RIEDEL, K., RASMUSSEN, T.B., BAGGE, N., KUMAR, N., SCHEMBRI, M.A., SONG, Z., KRISTOFFERSEN, P., MANEFIELD, M., COSTERTON, J.W., MOLIN, S., EBERL, L., STENBERG, P., KJELlEBERG, S., HØIBY, N., GIVSKOV, M. 2003. Attenuation of Pseudomonas aeruginosa virulence by quorum sensing inhibitors The EMBO Journal, 22, 2931-2944.

http://dx.doi.org/10.1093/emboj/cdg366

JAYANI, R.S., SAXENA, S., GUPTA, R. 2005. Microbial pectinolytic enzymes: a review. Process Biochemistry, 40, 2931-2944.

http://dx.doi.org/10.1016/j.procbio.2005.03.026

MCCLEAN, K.H., WINSON, M.K., FISH, L., TAYLOR, A., CHHABRA, S.R CAMARA, M., DAYKIN, M., LAMB, J.H., SWIFT, S., BYCROFT, B.W., STEWART, G.S.A.B., WILLIAMS, P. 1997. Quorum sensing and Chromobacterium violaceum: explotation of violacein production and inhibition for the detection of $\mathrm{N}$-acylhomoserine lactones. Microbiology, 143, 3703-3711. http://dx.doi.org/10.1099/00221287-143-12-3703

MEDINA-MARTIZNEZ, M.S., UYTTENDAELE, M., MEIREMAN, S., DEBEVERE, J. 2006. Relevance of N-acyl-L-homoserine lactone production by Yersinia enterocolitica in fresh foods. Journal of Applied Microbiology, 100, 1-9. http://dx.doi.org/10.1111/j.1365-2672.2006.03143.x

MYSZKA, K., CZACZYK, K. 2012. $N$-acylhomoserine lactones (AHLs) as phenotype control factors produced by gram-negative bacteria in natura ecosystems. Polish Journal of Environmental Studies, 21, 15-21.

LANE, R.E., JIANG, Y., CHHABRA, S.R., JACOB, S., STEWART, G.S.A.B., HARDMAN, A., DOWNIE, J.A., O'GARA, F., WILlIAMS, P. 2000. The biocontrol strain Pseudomonas fluorescens F113 producers the Rhizobium small bacteriocin, N-(3-hydroxy-7-cis-tetradecenoyl) homoserine lactone, via HdtS, a putative novel N-acylhomoserine lactone synthase. Microbiology, 16, 2469-2480.

LIU, M., GROFFTHS, W. 2003. The role of quorum sensing in the regulation of protease by Pseudomonas fluorescens and its relation to food spoilage. Annual Meeting Book Abstract, IFT, 268-296.

PARKAR, S.G., FLINT, S.H., PALMER, J.S., BROOKS, J.D. 2001. Factors influencing attachment of thermophilic bacilli to stainless steel. Journal of Applied Microbiology, 11, 675-685.

http://dx.doi.org/10.1046/j.1365-2672.2001.01323.x

RAGAERT, P., DEVLIEGHERE, F., DEBEVERE, J. 2007. Role of microbiological and physiological spoilage mechanisms during storage of minimally processed vegetables. Postharvest Biology and Technology, 44, 185 194.

http://dx.doi.org/10.1016/j.postharvbio.2007.01.001

RASCH, M., ANDERSEN, J.B., NIELSEN, K.F., RAVN FLOODGAARD, L. CHRISTENSEN, H., GIVSKOV, M., GRAM, L. 2005. Involvement of Bacterial quorum-sensing signals in spoilage of bean sprouts. Applied and Environmental Microbiology, 71, 3321-3330.

http://dx.doi.org/10.1128/aem.71.6.3321-3330.2005

RAVN, L., CHRISTENSEN, A.B., MOLIN, S., GIVSKOV, M., GRAM, L. 2001. Methods for detecting acylated homoserine lactones produced by gramnegative bacteria and their application in studies of AHL-production kinetics. Journal of Microbiological Methods, 44, 239-251.

http://dx.doi.org/10.1016/s0167-7012(01)00217-2

SIMON-SARKADI, L., HOLZAPFEL, W.H., HALASZ, A. 1993. Biogenic amine content and microbial contamination of leafy vegetables during storage at $5^{\circ} \mathrm{C}$. Journal of Food Biochemistry, 17, 407-418.

http://dx.doi.org/10.1111/j.1745-4514.1993.tb00483.x

SIEIDLE, A., SIGL, K., SCHUHEGGER, R., IHRING, A., SCHMID, M. GANTNER, S., STOFFELS, M., RIEDEL, K., GIVSKOV, M., HARTMAN, A., LANGEBARTELS, C., EBERL, L. 2001. Visualisation of N-acylhomoserine lactone-mediated cell-cell communication between bacteria colonizing the tomato rhizosphere. Applied and Environmental Microbiology, 67, 5761-5770. http://dx.doi.org/10.1128/aem.67.12.5761-5770.2001
SUAU, A., BONNET, R., SUTREN, M., GODON, J.J., GIBSON, G.R., COLLINS, M.D., DORE, J. 1999. Direct analysis of genes encoding 16S rRNA from complex communities reveals many novel molecular species within human gut. Applied and Environmental Microbiology, 65, 4799-4807.

VERKERK, R., SCHREINER, M., KRUMBEIN, A., CISKA, E., HOLST, B., ROWLAND, I., DE SCHRIHVER, R., HANSEN, M., GERHÄUSER, C. MITHEN, R., DEKKER, M. 2009. Glucosinolares in Brassica vegetables: the influence of the food supply chain on intake, bioavailability and human health. Molecular Nutrition and Food Research, 53, S219-S265. http://dx.doi.org/10.1002/mnfr.200800065

WHITEHEAD, N.A., BARNARD, A.M.L., SLATER, H., SIMPSON, N.J.L., SALMOND, G.P.C. 2001. Quorum-sensing in gram-negative bacteria. FEMS Microbiology Reviews, 25, 365-404.

http://dx.doi.org/10.1111/j.1574-6976.2001.tb00583.x

WU, H., SONG, Z., HENTZER, M., ANDERSEN, J.B., MOLIN, S., GIVSKOV, M., HØIBY, N. 2004. Synthetic furanones inhibit quorum-sensing and enhance bacterial clearance by Pseudomonas aeruginosa lung infections in mice. Journal of Antimicrobial Chemotherapy, 53, 1054-1061.

http://dx.doi.org/10.1093/jac/dkh223 